\title{
PENDAMPINGAN KONSELOR UNTUK PENCEGAHAN BURN OUT BELAJAR MELALUI KONSELING SENI KREATIF PADA KONDISI PANDEMI COVID-19
}

\author{
Agus Supriyanto*1, Hardi Prasetiawan ${ }^{2}$ \\ ${ }^{1,2}$ Universitas Ahmad Dahlan \\ *e-mail: agus.supriyanto@bk.uad.ac.id
}

\begin{abstract}
Abstrak
Pandemi COVID-19 berdampak pada pembelajaran di sekolah baik bagi siswa maupun guru. Siswa merasa bosan dan jenuh dengan pembelajaran online. Konseling seni kreatif merupakan intervensi yang dapat digunakan untuk mencegah, mengatasi, atau mengurangi kejenuhan siswa. Guru BK belum familiar dengan konseling seni kreatif untuk membantu siswa burnout di sekolah. Pendampingan merupakan upaya membantu guru BK mengenal dan mengembangkan diri untuk mencegah kejenuhan siswa dalam pembelajaran online. Metode pelayanannya adalah melalui proses brainstorming, konseling, dan pendampingan. Kegiatan pengabdian dilakukan kepada guru bimbingan dan konseling di Kabupaten Bantul dan Kulonprogo. Analisis pengukuran kondisi burnout siswa dengan metode wawancara tentang kondisi burnout siswa secara kualitatif. Pengukuran dampak hasil pendampingan terhadap pencegahan burnout dengan penyuluhan seni kreatif melalui wawancara dianalisis secara kualitatif. Pengukuran pemahaman konseling kreatif untuk membantu siswa burn out melalui angket yang dianalisis secara kuantitatif dengan metode standar deviasi dan persentase. Hasil brainstorming dengan guru BK, 75\% siswa mengalami kejenuhan belajar dengan indikator kelelahan dan kejenuhan mental, fisik, dan emosional. Konseling dilakukan untuk membantu guru BK menganalisis kondisi kejenuhan belajar siswa secara online dan konseling seni kreatif untuk membantu kejenuhan belajar siswa. Pendampingan kepada guru bimbingan dan konseling untuk mencegah, mengurangi, dan mengatasi kejenuhan belajar siswa. Hasil pendampingan adalah peningkatan kemampuan guru dalam penggunaan konseling seni kreatif sebesar $77,78 \%$, dan $8,33 \%$ guru yang belum dapat menggunakan konseling seni kreatif dan 13,89\% guru kain dalam penggunaan materi kreatif. konseling seni. Tindak lanjut dari kegiatan pendampingan tersebut adalah pelatihan layanan konseling seni kreatif untuk membantu siswa burnout.
\end{abstract}

Kata kunci: Burn Out, Konseling Seni Kreatif, Pandemi COVID-19

\begin{abstract}
The COVID-19 pandemic has had an impact on learning in schools for both students and teachers. Students feel bored and tired with online learning. Creative arts counselling is an intervention that can be used to prevent, overcome, or reduce student burnout. However, guidance and counselling teachers are not familiar with creative arts counselling to help students burn out. Mentoring is an effort to help guidance and counselling teachers know and develop themselves to prevent student burnout in online learning. The method of service is through the process of brainstorming, counselling, and mentoring. Service activities are carried out for guidance and counselling teachers in Bantul and Kulonprogo Regencies. Analyzed measurement of students' burnout conditions with the interview method about students' burnout conditions qualitatively. Measurement of the impact of mentoring results to prevent burnout with creative arts counselling through interviews analyzed qualitatively. Measurement of creative counselling understanding to help students burn out through a questionnaire analyzed quantitatively with standard deviation and percentage methods. The result of brainstorming with guidance and counselling teachers is that $75 \%$ of students experience learning burnout with mental, physical, and emotional exhaustion and saturation indicators. Counselling is carried out to help guidance and counselling teachers analyze online student learning burnout and creative arts counselling to help student learning burnout. Assistance to guidance and counselling teachers to prevent, reduce, and overcome student learning burnout. The result of the mentoring is an increase in the ability of teachers in the use of creative arts counselling by $77.78 \%$, and $8.33 \%$ of teachers who have not been able to use creative arts counselling and $13.89 \%$ of rag teachers in the use of creative arts counselling. The follow-up to the mentoring activity was training on creative arts counselling services to help student's burnout.
\end{abstract}

Keywords: Burnout, Creative Arts Counseling, COVID-19 Pandemic 


\section{PENDAHULUAN}

Pendidikan sebagai bagian yang komprehensif dalam proses kehidupan. Pendidikan sebagai proses sengaja dan proses alamiah (Mu'in, 2011). Pendidikan merupakan upaya pengembangan kepribadian yang dapat terimplikasi dengan didalam masyarakat (INDONESIA, 2003). Persoalan mendasar dalam dunia pendidikan yang akhir-akhir ini sering menjadi perhatian bersama semenjak masyarakat diresahkan dengan adanya wabah Corona Virus Disease (Covid-19) yang menjadi sebuah pendemi yaitu burnout yang sangat berdampak pada peserta didik di sekolah (Elisabeth, 2020). Saat ini pemerintah memberikan kebijakan kegiatan pembelajaran atau layanan bimbingan dan konseling dilakukan dari rumah atau peserta didik belajar secara daring dan tidak berangkat ke sekolah. COVID-19 memiliki dampak buruk pada pendidikan antara lain, gangguan belajar, dan penurunan akses ke fasilitas pendidikan dan penelitian, hilangnya pekerjaan dan peningkatan hutang siswa, kemudian pendidikan online terhambat oleh infrastruktur yang buruk termasuk, jaringan, listrik, masalah tidak dapat diaksesnya dan tidak tersedianya serta keterampilan digital yang buruk (Onyema et al., 2020).

Fenomena burnout sebagai dampak dari pembelajaran online. Kejenuhan belajar siswa mengalami kejenuhan belajar, kelelahan emosi, kelelahan fisik, kelelahan kognitif, dan kehilangan motivasi (Ningsih, 2016). Fakta lagi pad kondisi tatap muka sebelum pandemic covid-19 bahwa 60,45\% siswanya mengalami kejenuhan belajar (Purnama, 2016). Penelitian lain dilakukan oleh yang meneliti tentang perbedaan tingkat kejenuhan belajar pada siswa laki-laki lebih tinggi dibandingkan perempuan (Jatmiko, 2016). Pada kondisi pandemic covid-19, pembelajaran online membuat siswa juga merasa jenuh. Keadaan darurat kesehatan pada kondisi pandemic covid-19 menempatkan tuntutan berat pada kualitas lingkungan belajar online (Erduran, 2020). Pembelajaran online dan telekonferensi adalah solusi solusi inovatif sebagai pengganti kuliah tatap muka (Chick et al., 2020).

Banyaknya aktivitas belajar online serta tugas rumah sebagai penyebab munculnya gejala-gejala burnout. Gejala burnout dalam bentuk kelelahan pada seluruh indera manusia, kurang pehatian, bosan, kurang bersemangat, kurang motivasi, tidak ada minat belajar, dan kurang pehatian (Khusumawati, 2015). Burnout belajar terkait stres, beban atau faktor psikologis. Siswa terasa kelelahan emosional, perasaan tidak bisa berpreastasi, dan kecenderungan untuk depersonalisasi. Dampak burn out siswa dalam pembelajaran online adalah kurangnya sentuhan pribadi, interaksi, peran karena masalah koneksi sebagai kekurangan dari kelas virtual atau online (Arora \& Srinivasan, 2020).

Burnout belajar harus mendapatkan intervensi yang tepat dari konselor sekolah bekerjasama dengan stakeholders (keluarga, masyarakat, dan guru mata pelajaran, staf tata usaha, komite, dan pimpinan sekolah). Guru bimbingan dan konseling berperan untuk pengentasan burnout belajar. Tuntutan profesi yang ditetapkan dalam standar kompetensi konselor mampu mengimplementasikan layanan bimbingan dan konseling yang kreatif (Sutarjo et al., 2014). Kenyataannya Permasalahan yang terjadi di pada guru Bimbingan dan Konseling di wilayah Kulon Progo belum banyak yang menerapkan konseling kreatif dengan seni visual.

Hasil analisis dari informasi guru bimbingan dan konseling bahwa kompetensi profesional dalam impelemntasi layanan bimbingan dan konseling sering menjadi hambatan bagi konselor terutama dalam membangun dan mengatasi burnout pada remaja. Intervensi dengan kegiatan pendampingan untuk pengembangan diri guru bimbingan dan konseling tentang konseling seni kreatif untuk pencegahan burn out siswa. Kajian literatur menunjukkan bahwa konseling seni kreatif memberikan dampak positif bagi siswa serta memberikan wawasan bagi siswa (Reynolds et al., 2000). Konseling seni kreatif sebagai 
kombinasi seni dan konseling untuk membangun hubungan konselor dan konseli dan sebagai intervensi yang efektif (Feen-Calligan, 2012; Randick \& Dermer, 2013).

Integrasi layanan konseling dengan pendekatan konseling seni kreatif, serta penggunaan teknologi relevan digunakan selama pandemic COVID-19. Hasil penelitian mengungkap fakta bahwa media asinkron dan media sinkron berbasis teknologi menjadi alternatif utama layanan konseling online di masa pandemi COVID-19 (Supriyanto et al., 2020). Seluruh alternatif layanan konseling pada kondisi pandemic COVID-19 harus mampu mengembangkan diri siswa dan juga konselor sekolah. Layanan konseling dengan seni kretaif sebagai alternatif tepat yang dapat diimplementasikan untuk pencegahan burn out siswa secara sinkron.

Konseling seni kreatif dalam seni visual meningkatkan kualitas layanan konseling, kemudian dapat mengungkapkan konflik rahasia yang tidak terungka, melambangkan perasaan, menginspirasi siswa untuk pertumbuhan pribadinya, membantu agar tidak merasa terancam, serta mudah dipadukan dengan Gerakan, tulisan, dan citra dalam seni kreatif (Alhadi \& Saputra, 2017). Seni Rupa dalam konseling kreatif juga membantu konseli yang sulit mengungkapkan masalahnya secara verbal (Rahmi \& Nurhasnah, 2020). Konseling dengan seni kreatif musik dapat pula menghindari kecemasan siswa dalam pembelajaran (Situmorang, 2018). Berbagai kajian mendasar dari konseling seni kreatif menjadi keterampilan yang urgen untuk guru bimbingan dan konseling dalam rangka pencegahan burn out siswa. Pendampingan bagi guru untuk pengembangan diri dalam layanan konseling kreatif menjadi urgenitas. Tujuan pengabdian ini adalah pengembangan diri guru bimbingan dan konseling untuk pencegahan burn out siswa dalam pembelajaran online.

\section{METODE}

Pendampingan kepada guru bimbingan dan konseling. Metode yang digunakan dalam kegiatan ini dalah brainstorming, penyuluhan, dan pendampingan. Brainstroming dalam kegiatan ini adalah terkait analisis fenomena tentang kondisi burn out siswa selama pembelajaran online sejak 2020-2021. Brainstorming dilaksanakan dengan kepada Ketua Musyawarah Guru Bimbingan dan Konseling (MGBK) Kulonprogo dan Bantul, serta Pengurus Daerah Muhammadiyah (PDM) Kulonprogo dan Bantul, Daerah Istimewa Yogyakarta. Penyuluhan dirancang dalam kegiatan webinar atau web seminar. Materi webinar tentang analisis kondisi burn out pada siswa pada pembelajaran online, hasil dari brainstorming. Materi kedua adalah peran layanan konseling seni kreatif untuk membantu kondisi burn out siswa. Kemudian pendampingan layanan konseling seni kreatif untuk membantu mencegah, mengatasi, maupun mereduksi kondisi burn out siswa.

Analisis kegiatan pengabdian tentang pencegahan, pengentasan, maupun reduksi kondisi burn out melalui layanan konseling seni kreatif dengan analisis kualitatif dan kuantitatif. Tingkat pencapaian hasil pengabdian melalui analisis kuantitatif tentang pemahaman dan pengenalan konseling seni kreatif untuk mampu membantu kondisi burn out siswa melalui standar deviasi dan presentase. Analisis kondisi burn out melalui studi analisis dari kegiatan brainstorming. Analisis dampak hasil pendampingan melalui analisis kualitatif, sehingga diketahui kebermanfaatannya. Kemudian hasil analisis kualitatif dan kuantitatif, sebagai tindak lanjut dari kegiatan selanjutnya.

\section{HASIL DAN PEMBAHASAN}

Pendampingan guru bimbingan dan konseling untuk membantu burnout siswa melalui layanan konseling seni kreatif diawali forum group discussion (FGD) dengan 
Musyawarah Guru Bimbingan dan Konseling (MGBK) Kulonprogo dan Bantul, serta Pengurus Daerah Muhammadiyah (PDM) Kulonprogo dan Bantul. Hasil dari FGD mendapatkan fakta tentang fenomena burnout pada pembelajaran online dengan kondisi pandemic COVID-19. Informasi dari konselor sekolah tentang kondisi burnout siswa selama pembelajaran daring atau online bahwa $75 \%$ siswa mengalami kondisi burnout, 22,92\% siswa kemungkinan mengalami burnout, dan hanya 2,08\% siswa tidak mengalami burnout.

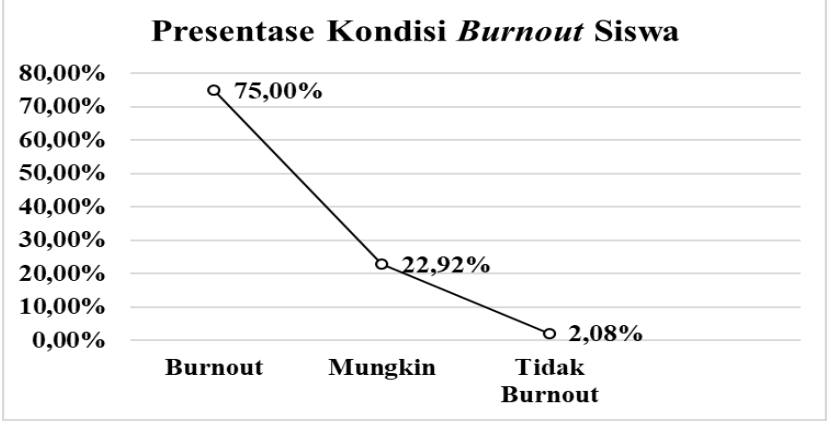

Gambar 1. Burnout Siswa (\%)

Hasil wawancara kepada siswa menunjukkan bahwa siswa mengalami burnout dengan kondisi lelah secara fisik, mental, dan emosional tentang pembelajaran daring. Hasil wawancara mendapatkan fakta bahwa burnout fisik dalam pembelajaran daring adalah terjadinya kelelahan setiap hari, sakit, sulit tidur, dan gangguan makan. Selain itu burnout emosional berdampak pada kecemasan siswa, perasaan bersalah, perasaan gagal, hilang kendali dalam belajar, dam ketakutan berlebihan. Adapula burnout mental siswa berdampak pada kesulitan kognitif siswa dalam pembelajaran dan hilangnya makna dan harapan belajar.

Tabel 1. Kondisi Burnout Siswa

\begin{tabular}{|c|c|c|}
\hline Variabel & Indikator & Kondisi Burnout Siswa \\
\hline $\begin{array}{c}\text { Burnout } \\
\text { siswa dalam } \\
\text { pembelajaran } \\
\text { daring atau } \\
\text { online }\end{array}$ & Emosional & $\begin{array}{l}\text { 1. Pembelajaran daring tidak menarik dan membosankan, pembelajaran praktek } \\
\text { lebih sulit untuk dikerjakan, dan tidak tertarik dengan pembelajaran daring } \\
\text { 2. Pekerjaan rumah dilaksanakan di rumah dan kerja kelompok secara online } \\
\text { 3. Sulit untuk menangkap materi pembelajaran karena koneksi dan metode guru } \\
\text { yang kurang kreatif. } \\
\text { 1. Kondisi fisik siswa menurun, mereka merasa capek, lesu, tidak bertenaga } \\
\text { selama menjalani pembelajaran dan tugas yang banyak } \\
\text { 2. Siswa mengalami sakit karena terlalu banyak begadang, terlalu lama menatap } \\
\text { layar laptop atau hp untuk mengerjakan tugas atau melakukan pembelajaran } \\
\text { daring } \\
\text { 3. Jam tidur siswa berantakan dan tidak teratur } \\
\text { 4. Pola makan siswa berantakan dan tidak teratur } \\
\text { 1. Siswa merasa cemas, tidak tenang, dan kesepian karena harus terus di rumah } \\
\text { dan kesulitan pembelejaran daring. } \\
\text { 2. Siswa menyalahkan diri sendiri karena tidak paham apa yang diajarkan guru } \\
\text { dan sulit mengerjakan tugas yang diberikan } \\
\text { 3. Siswa merasa pembelajaran daring tidak efektif. } \\
\text { 4. Siswa memiliki kesulitan terhadap pembagian waktu belajar dan pekerjaan } \\
\text { rumah. } \\
\text { 5. Siswa yang berpikir bahwa pembelajaran daring akan terus dilakukan } \\
\text { berdampak materi ilmu yang didapatkan. }\end{array}$ \\
\hline
\end{tabular}

Fenomena terjadinya burnout pada diri siswa, maka pengabdian pendampingan konselor sekolah sebagai bantuan untuk kondisi burnout siswa. Intervensi yang tepat melalui penyuluhan dan pendampingan dalam layanan konseling seni kreatif yang dapat dilaksanakan secara online dan offline dengan tetap memathu protocol kesehatan. Penyuluhan dan pendampingan kepada guru bimbingan dan konseling melalui online dan offline. Penyuluhan 
secara online dalam penggunaan konseling seni kreatif melalui kegiatan webinar konseling seni kreatif untuk membantu burnout siswa selama pandemic COVID-19. Pendampingan secara offline adalah workshop penggunaan layanan konseling seni kreatif.

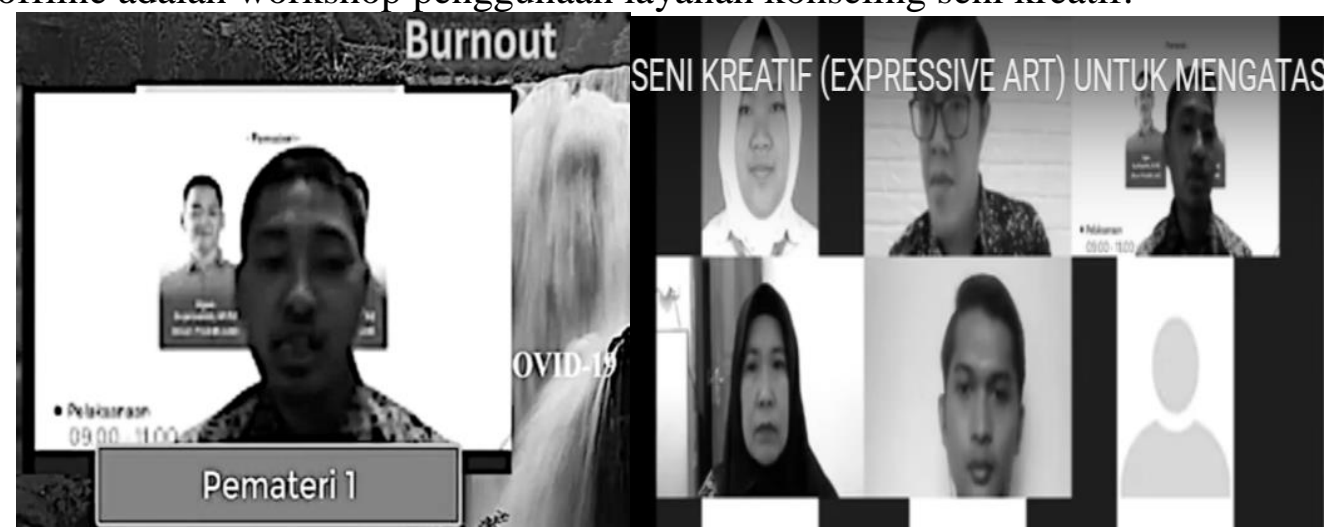

Gambar 2. Penyuluhan tentang Analisis Burnout Siswa pada Pembelajaran Daring dan Penggunaan Konseling Seni Kreatif untuk Membantu Kondisi Burnout Siswa

Penyuluhan secara online atau tatap maya dilaksanakan dengan pemateri 1 tentang analisis burnout siswa pada pembelajaran daring pada kondisi pandemi COVID-19. Hasil dari penyuluhan ini adalah guru bimbingan dan konseling mampu menganalisis tentang kemungkinan kemungkinan tentang kondisi burnout yang dapat dialami oleh siswa. Kemudian pemateri kedua memberikan informasi tentang penggunaan konseling kreatif untuk membantu kondisi burnout siswa. Kemudian selain kegiatan penyuluhan, adanya pendampingan kepada guru bimbingan dan konseling secara offline atau tatap muka. Pendampingan sebagai upaya tim pengabdian membantu konselor sekolah untuk pengembangan keterampilan penggunaan konseling seni kreatif untuk membantu pencegahan, pengentasan, maupun reduksi burnout siswa.

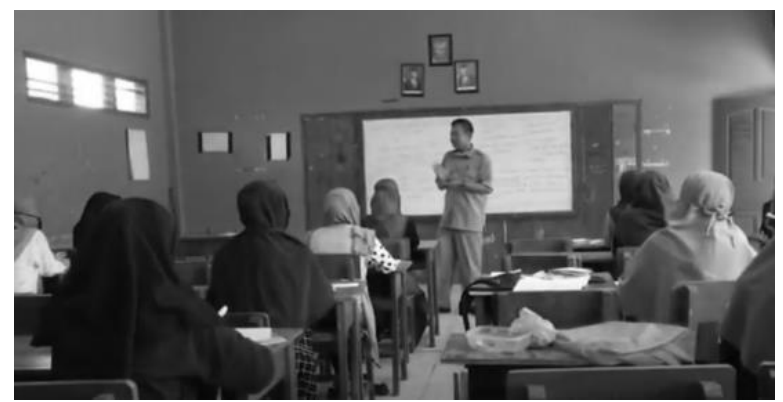

Gambar 3. Pendampingan Penggunaan Konseling Seni Kreatif untuk Membantu Masalah Burnout Siswa

Hasil dari pengabdian memunculkan pemahaman guru dalam penggunaan konseling seni kreatif untuk membantu kondisi burnout siswa. Sebelum kegiatan pendampingan, sebanyak 8,33\% telah mengenal dan mampu menggunakan konseling senin kreatif. Kemudian setelah pendampingan, 77,78 guru bimbingan dan konseling telah mampu menggunakan konseling seni kreatif untuk membantu siswa yang mengalami burnout. Data selanjutnya menunjukkan bahwa awalnya 51,39\% guru bimbingan dan konseling ragu untuk mampu menggunakan konseling seni kreatif, kemudian keraguan turun menjadi 13,89\%. Kemudian pada awalnya guru bimbingan dan konseling merasa belum bida menggunakan konseling seni kreatif sebesar 40,28\% turun menjadi $8,33 \%$. Dari data ini selanjutnya perlunya workshop secara khusus untuk pendampingan intens dalam rangka pengembangan profesionalisme guru 
bimbingan dan konseling, terkhusus penggunaan konseling seni kreatif untuk membantu masalah burnout siswa.

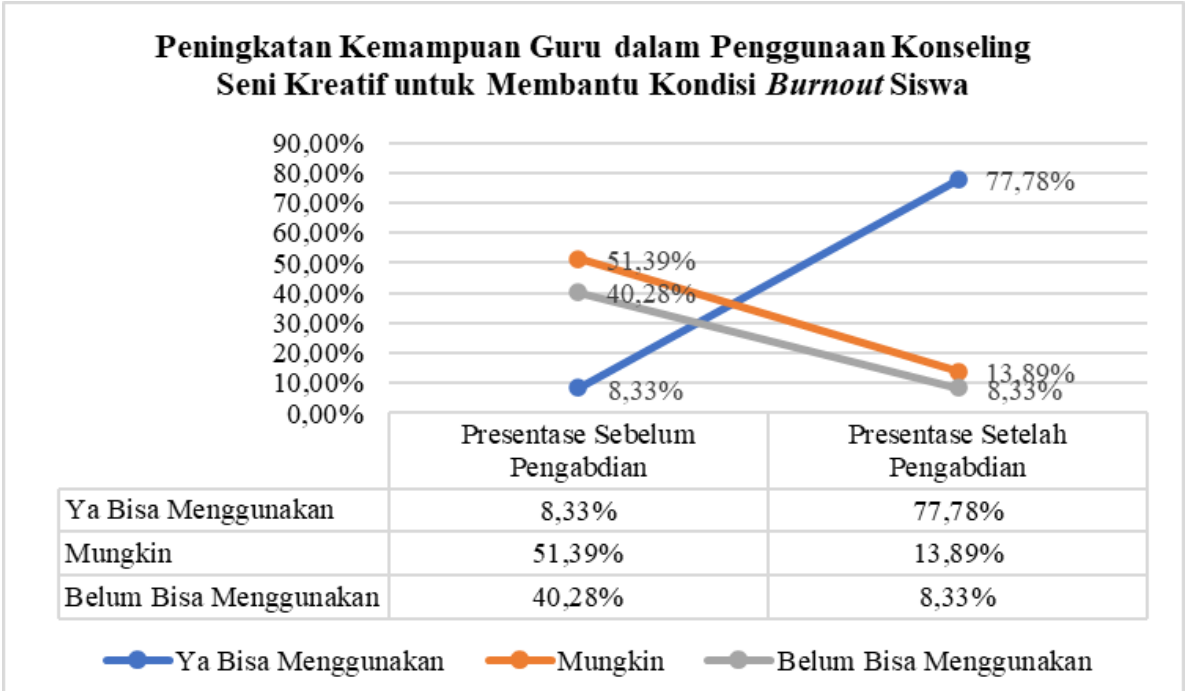

Gambar 4. Peningkatan Kemampuan Guru Bimbingan dan Konseling dalam Penggunaan Konseling Kreatif untuk Membantu Masalah Burnout Siswa dalam Pembelajaran Online atau Daring

Pendampingan kepada guru bimbingan dan konseling untuk mencegah, mereduksi, maupun mengatasi burnout siswa melalui layanan konseling seni kreatif sebagai intervensi yang relevan pada kondisi pandemic COVID-19. Konselor sekolah dapat mengantisipasi perubahan pola belajar dan memerlukan pendampingan secara tepat pada selama pembelajaran pada kondisi pandemic COVID-19 (Nugroho, 2020). Konseling seni kreatif yang dilaksanakan dalam kegiatan ini menggabungkan beberapa teknologi seperti music, tari, seni rupa, seni tulis, dan berbagai seni yang dapat digunakan secara online.

Kompetensi penggunaan teknologi oleh guru bimbingan dan konseling bermanfaat dalam pelayanan bimbingan dan konseling (Cahyawulan et al., 2019). Selain pendampingan perlunya pelatihan yang menunjang kemampuan guru bimbingan dan konseling. Pelatihan membuat guru merasa antusias, serius, dan dapat mempraktikan secara langsung (Triyono et al., 2019). Perlu pula pengawasan dan koordinasi dengan kepala sekolah untuk keefektifan layanan bimbingan dan konseling (Luddin, 2013), terkhusus kondisi burnout belajar siswa.

\section{KESIMPULAN}

Hasil analisis terkait burnout siswa adalah $75 \%$ siswa mengalami kondisi burnout, kemudian sebesar 22,92\% siswa kemungkinan mengalami burnout, dan hanya 2,08\% siswa tidak mengalami burnout. Burnout siswa dalam pembelajaran online berdampak pada tiga indikator yaitu fisik, mental, dan emosional. Layanan konseling seni reatif membantu burnout siswa. Penyuluhan tentang analisis kondisi burnout siswa dan juga penggunaan konseling seni kreatif membantu burnout siswa sebagai yang integral untuk intervensi pencegahan, pengentasan, dan reduksi kondisi burnout. Selanjutnya pendampingan penggunaan layanan konseling seni kreatif membantu siswa untuk mengatasi atau mencegah ataupun mereduksi burnout. Hasil dari pengabdian adalah adanya peningkatanan kemampuan guru dalam menggunakan konseling seni kreatif untuk mencegah atau mengatasi atau mereduksi burnout sebesar 77,78\%, walaupun masih ada guru sebesar 8,33\% belum mampu menggunakan konseling seni kreatif dan 13,89\% ragu dalam penggunaan konseling seni kreatif. Pengabdian ini terbatas pada pendampingan kepada guru bimbingan dan konseling, sehingga perlunya pendampingan melalui pelatihan konseling seni kreatif untuk burnout belajar. 


\section{UCAPAN TERIMA KASIH}

Ucapan terima kasih disampaikan kepada Musyawarah Guru Bimbingan dan Konseling (MGBK) di Wilayah Bantul dan Wilayah Kulonprogo, serta Pengurus Daerah Muhammadiyah (PDM) Bantul dan Kulonprogo. Fasilitasi dalam komunikasi dan proses pelaksanaan pendampingan dapat membantu keterlaksanaan pendampingan. Selain membantu proses kegiatan, kami dapat mengembangkan profesi guru bimbingan dan konseling.

\section{DAFTAR PUSTAKA}

Alhadi, S., \& Saputra, W. N. E. (2017). Integrasi Seni Kreatif dalam Konseling dengan Pemanfaatan Seni Visual. Jurnal Fokus Konseling, 3(2), 108-113.

Arora, A. K., \& Srinivasan, R. (2020). Impact of pandemic COVID-19 on the teachinglearning process: A study of higher education teachers. Prabandhan: Indian Journal of Management, 13(4), 43-56.

Cahyawulan, W., Badrujaman, A., Fitriyani, H., Mamesah, M., Wahyuni, E., \& Djunaedi, D. (2019). Peningkatan kompetensi teknologi dan informasi guru bimbingan dan konseling. CARADDE: Jurnal Pengabdian Kepada Masyarakat, 1(2), 195-199.

Chick, R. C., Clifton, G. T., Peace, K. M., Propper, B. W., Hale, D. F., Alseidi, A. A., \& Vreeland, T. J. (2020). Using technology to maintain the education of residents during the COVID-19 pandemic. Journal of Surgical Education, 77(4), 729-732.

Diana Septi Purnama, S. (2016). Model bimbingan pengembangan kompetensi pribadi sosial bagi siswa sma yang mengalami kejenuhan belajar (burnout).

Elisabeth, C. (2020). Burnout Akademik Selama Pandemi Covid 19. In Prosiding Seminar Bimbingan dan Konseling, 8-15.

Erduran, S. (2020). Science Education in the Era of a Pandemic. Springer.

Feen-Calligan, H. R. (2012). Professional identity perceptions of dual-prepared art therapy graduates. Art Therapy, 29(4), 150-157.

INDONESIA, D. (2003). Undang-Undang Rebuplik Indonesia nomor 20 tahun 2003 tentang sistem pendidkan Nasional. Jakarta: Departemen Pendidikan Nasional.

Jatmiko, R. B. (2016). Perbedaan tingkat burnout belajar siswa laki-laki dan perempuan kelas VIII di SMP Negeri 3 Pedan. Jurnal Riset Mahasiswa Bimbingan Dan Konseling, $5(2)$.

Khusumawati, Z. E. (2015). Penerapan kombinasi antara teknik relaksasi dan self-instruction untuk mengurangi kejenuhan belajar siswa kelas XI IPA 2 SMA Negeri 22 Surabaya. Jurnal BK UNESA, 5(1).

Luddin, A. B. M. (2013). Kinerja kepala sekolah dalam kegiatan bimbingan dan konseling. Jurnal Ilmu Pendidikan, 19(2).

Mu'in, F. (2011). Pendidikan karakter: Konstruksi teoretik \& praktik. Yogyakarta: Ar Ruzz Media.

Ningsih, F. (2016). Efektifitas teknik relaksasi untuk mengurangi kejenuhan belajar. 7(5).

Nugroho, G. B. (2020). Peran guru bimbingan dan konseling dalam pendampingan belajar siswa selama pembelajaran online. Psiko Edukasi, 18(1), 73-83.

Onyema, E. M., Eucheria, N. C., Obafemi, F. A., Sen, S., Atonye, F. G., Sharma, A., \& Alsayed, A. O. (2020). Impact of Coronavirus pandemic on education. Journal of Education and Practice, 11(13), 108-121.

Rahmi, A., \& Nurhasnah, N. (2020). Pengembangan Modul Seni Kreatif dalam Memberikan Layanan Bimbingan Konseling Inovatif. Islamic Counseling: Jurnal Bimbingan Dan Konseling Islam, 4(2), 163-180. 
Randick, N. M., \& Dermer, S. B. (2013). The relationship of school art therapy and the American School Counselor National Model. Art Therapy, 30(1), 30-35.

Reynolds, M. W., Nabors, L., \& Quinlan, A. (2000). The effectiveness of art therapy: Does it work? Art Therapy, 17(3), 207-213.

Situmorang, D. D. (2018). Academic anxiety sebagai distorsi kognitif terhadap skripsi: Penerapan konseling cognitive behavior therapy dengan musik. Journal of Innovative Counseling: Theory, Practice, and Research, 2(02), 100-114.

Supriyanto, A., Hartini, S., Irdasari, W. N., Miftahul, A., Oktapiana, S., \& Mumpuni, S. D. (2020). Teacher professional quality: Counselling services with technology in Pandemic Covid-19. Counsellia: Jurnal Bimbingan Dan Konseling, 10(2), 176-189.

Sutarjo, I. P. E., Dewi Arum Widhiyanti Metra Putri, S. P., \& Prof. Dr. Ni Ketut Suarni, M. S. (2014). Efektivitas teori behavioral teknik relaksasi dan brain gym untuk menurunkan burnout belajar pada siswa kelas VIII SMP LABORATORIUM UNDIKSHA Singaraja Tahun Pelajaran 2013/2014. Jurnal Jurusan Bimbingan Konseling Undiksha, 2(1),

Triyono, T., Febriani, R. D., Hidayat, H., \& Putri, B. N. D. (2019). Pelatihan penggunaan teknologi informasi kepada guru bimbingan dan konseling. WAHANA DEDIKASI, 2(1). 